\title{
Dead Volume
}

National Cancer Institute

\section{Source}

National Cancer Institute. Dead Volume. NCI Thesaurus. Code C48042.

Any volume which a component introduces to a system that is not cleanly swept and relies on diffusion to clear the space; a dead-end passag eway or cavity that can retain materials to contaminate subsequent samples or flow media. 